\title{
The Camellia Swinging in the Storm-- A View on Awakening of Women's Self-consciousness in the East and West from the Comparison between the Tragic Fate of Marguerite and Chen Bailu
}

\author{
Yueying Yao \\ School of foreign languages, Changchun Institute of Technology, Changchun, Jilin, 130012, China
}

Keywords: Alexandre Dumas, Cao Yu, Marguerite, Chen Bailu, Feminism, Comparison.

\begin{abstract}
In the novel Camellias (La Dame aux Camélias), the French writer Alexandre Dumas tells us about the lingering love story of the party girl Marguerite. Margaret is a typical woman at the bottom of the emancipating society in the developed period of French capitalism. She has produced a weak awakening and resistance for love in order to change her tragic fate. This is the patriarchal rule and the awakening of women's own consciousness, which is the inevitable result of the conflict. Since the twentieth century, especially since the May Fourth Movement, China's own social system has undergone tremendous changes. At the same time, under the influence of Western feminist consciousness, Chinese female literature has finally broken away from the shackles of male standardism and has achieved fundamental development. The drama Sunrise by Chinese dramatist Cao $\mathrm{Yu}$ shows the awakening of female consciousness by telling us about the tragic life of social white Chen Bailu. This paper will explore the awakening of women's consciousness in the East and West through the comparison of Marguerite and Chen Bailu.
\end{abstract}

\section{Introduction}

Since the 1950s, feminism has developed infinitely in France. The feminist trend of thought has gradually gained people's approval, and women's self-awareness has also awakened. They demanded equal legal rights, demanded to get rid of the suppression and restraint of women in the patriarchal society, gain independent ideology, and launched a campaign of resistance. In this social context, the French writer Alexandre Dumas gave birth to Marguerite, a female image of the underlying society that is awakened by women. In China, under the old tradition of thousands of years, the status of women has always been humble, completely dominated and dominated by the patriarchal society. Since the May Fourth Movement, new literary writers have been tempted by the oppression and restraint of old ideas. In the process of seeking individual liberation, women gradually move toward awakening. Under the influence of the trend of freedom and equality and ideological emancipation, Chinese dramatist Cao $\mathrm{Yu}$ has created Chen Bailu, an intellectual woman with a spirit of resistance who pursues freedom of love and marriage in Sunrise, a typical example of female self-consciousness. This paper will discuss at the similarities and differences between the East and West feminist consciousness awakening from the background of the two authors, the oppression and enslavement of the two heroines, and their final choice and destiny.

\section{Different backgrounds, same consciousness}

In the mid-nineteenth century, France was in the period of the July Dynasty, when capitalism was highly developed. At this time, the Constitution has abolished the personal attachment relationship of the feudal society, and clearly stipulates that everyone has the right to equality and freedom. Therefore, with the deepening of the minds of freedom and equality, feminism has also flourished. But at the time, the ruling class in France was very corrupt, and the people at the bottom of the society were living a hungry and cold life. Therefore, there are also hierarchical concepts in society, and women at the bottom of society are underestimated. In this era of ideological change, Marguerite, the 
social flower of Alexandre Dumas, fought for the pursuit of freedom of love. Her behavior reflects the free and equal thoughts given to her by the society at the time and represents the awakening of feminist consciousness. Her tragic fate comes from the fierce conflict between the bourgeoisie's pursuit of freedom and equality, individual liberation and the concept of hierarchy.

Marguerite is a typical representative of a woman with a female consciousness in the period of social change in France in the 1950s. This female image is a huge improvement in the description of women in French literature. Before Alexandre Dumas, no French writer used such a true and natural style to describe a story in which a girl whose appearance and heart is as pure and beautiful was devastated. In Camille, Alexandre Dumas described Marguerite's purity and kindness, the passionate pursuit of love freedom and the suppression and restraint of the patriarchal society. This is also the main reason Camille has been sparkling in the world literary world since its introduction in the 1850s.

The protagonist Marguerite is a poor country girl. She came to Paris to make a living, unfortunately became a courtesan, and in the extravagant and splendid living environment, she squandered the bad habit of squandering pleasure. But Marguerite still maintains a pure heart. She cherishes love and longs for freedom. During the French dynasty in July, although the Constitution provided for the right to freedom and equality, the feudal ideology was still quite powerful. Therefore, Marguerite's pursuit of love freedom and individual liberation must be bound by the feudal ideology and frustration. Marguerite is delicate and fragile, like white tea flowers. Under the ruin of maleism and feudalism, she has not retreated at all. She wrote a song of love freedom with her own life, which fully reflects Marguerite's awakening of feminist ideas.

France is the birthplace of feminism. Completely different from France, in China, the real awakening of female consciousness began with the May Fourth Movement. The booming feminist movement and feminist trends in Europe have greatly inspired the Chinese who are eager to change and desire freedom and equality. Since the May Fourth Movement, the literary revolution broke out in the Chinese literary world. New literary writers have described the discovery of "people" in their literary works, especially the discovery of "women". The May Fourth literary revolution led the wave of women's liberation and brought about the awakening of feminist consciousness.

Before the May Fourth Movement, women were deeply bullied by feudal ideology and patriarchalism and have been marginalized in society. The emergence of the heroine in Cao Yu's work is a landmark event in the modern Chinese literary world and a self-rescue to the tragic fate of women. In Sunrise, Chen Bailu learned to struggle and pursue in the dark society. Cao Yu gives Chen Bailu the initiative and choice to break away from the male-centered mindset. This broke the feudal patriarchal ideology and system for thousands of years. Women are no longer affiliated with marginalization, but become a group independent of men. Although the fate of female Chen Bailu written by Cao Yu is tragic, they shouted to the society in this tragic and dead way, letting people see the strong desire of women to break free from the bondage of male power and the pursuit of freedom of love.

\section{Different dreams, the same choice}

Marguerite was originally a good-natured rural girl. She was born at the end of the "July Dynasty". Under the double oppression of the landlord and the bourgeoisie, the peasants went bankrupt. Like many bankrupt farmers, she came to the city from the countryside in order to find a way out of her life, and earned a living by selling labor. Marguerite's dream is the same as that of the working people at the bottom of society. She hopes to live a happy life through her hard work. However, Marguerite, who first entered the Parisian society, witnessed the sharp conflict between the emerging bourgeoisie and the remnants of feudalism during his life. In such a society, the weak and weak women face a huge temptation: one is the hopeless life that cannot be replaced by the hard work and the bullying, but the other side is the luxury of the drunken fans. . In the end, in order to get rid of the poor life, Marguerite chose the way to get a living guarantee. An innocent working woman has become a courtesan and has become a plaything and commodity attached to males in a patriarchal society.

Chen Bailu is a modern intellectual woman who pursues individual freedom and liberation. She 
shoulders the enlightenment task of women's new ideas since the May Fourth Movement, and carries the conflict between feudal traditional thought and modern equality consciousness. Therefore, while conflicting with the old social ethics and resolutely rebelling against the shackles of male ideology, she also sought out the difficult choices that new women could make in the new era. Chen Bailu's dream carries the sacred mission of intellectual women since the May Fourth Movement to create their own modern character---without the shackles of feminist rule and feudalism, becoming an independent existence that pursues freedom and equality and can control their own destiny. . Chen Bailu has the courage to break the shackles of old ethics and morality, to find new life goals, and hopes to rely on his own ambition to win his own true happy life. However, under the cruel social reality, Chen Bailu is absolutely impossible to achieve her own ideals, so although she has ambitions, in reality, she has chosen to become an urban courtesan that relies on men to make a living.

\section{Different restraints, the same ending}

In the patriarchal society that has lasted for thousands of years, women have been marginalized. They do not have the right to participate in politics, the right to receive education, or the right to participate in social decision-making, so of course, they have no ability to decide their own destiny. For Marguerite, a woman who travels to the city from a poor rural area, fate is already doomed for Chen Bailu, who is not satisfied with the old ethics and bounds to go to the big cities to pursue freedom and happiness. In the cultural context of patriarchalism, women are the weaker men, and they are male-centered. They can only survive if they fully commit themselves to the female's affiliated role and play the weak or pet sheltered by men. Otherwise, their ending can only be death.

In the development of the story, Marguerite did not believe in love at first, was humiliated in the dirty society; then she fell in a luxurious and splendid life, and she was extremely submissive to men at this time. However, from the rejection of Armand to the attraction of Armand, Marguerite's feminist consciousness began to awaken, rebel against male power, and struggled with the patriarchal society. She wants to pursue free love to change her unfortunate life. During this period, her female awakening consciousness was developed. Later, Marguerite regressed masculinity for the future of Armand, and the awakened female consciousness was suppressed and restrained at this time. However, Marguerite finally chose the way of death to launch the greatest resistance to the patriarchal society. She used her life to call and scream, when her female consciousness awakened to a climax.

Chen Bailu fell in love, got married, then divorced, and finally fell into a courtesan, but she was not a veteran woman. Her innocence is similar to Camille. It's just that she doesn't hope for love, but she puts hope on herself. This is the awakening of her female consciousness, to get rid of the shackles of patriarchism. Chen Bailu wants to do what she wants and wants to save the little guy. This conscious rebellion against the patriarchal society and the ruling class means that her feminist awakening has developed greatly. But the reality is so cold and ruthless, she finally got only disappointment. Because she could not rescue the little guy from the masculine dominating society, and was forced to pay debts and lover bankruptcy, she also chose to fight in a way of death when her feminist consciousness was hit. This silent struggle reflects Chen Bailu's determination and courage to resist the patriarchal society, revitalizing and redeeming her own soul, and bringing her feminist awakening to its peak.

\section{Summary}

In Alexandre Dumas's novel Camille, Marguerite's tragic life looks like the epitome of women at the bottom of France's society. But Marguerite is a French woman under the influence of feminist thoughts. She is not willing to be bound by patriarchalism and pursues a happy life centered on pure love. This is the requirement of the bourgeoisie to pursue individual liberation. It is the confrontation between the bourgeois free and equal thought and the hypocritical feudal residual thought. It is one of the symbols of the awakening of feminist consciousness. This was of great historical progress in 
France at the time. Cao Yu's script Sunrise was a symbol of the awakening of feminist consciousness in Chinese society at that time. It was an outstanding representative of the sharp equality of thoughts and patriarchism since the May Fourth Movement. This also had far-reaching social significance in China at the time. These two works are produced in different eras and different backgrounds. They are created by two male authors from different countries, but they all show the awakening of feminist consciousness in the ideological change of free and equal thought and patriarchal confrontation. From the comparison of the two works, it can be seen that the awakening of the female consciousness in the East and the West has different conditions, and the depth of the awakening is different. In general, the awakening and development of Western female consciousness is earlier and more thorough than the awakening of Eastern female consciousness.

\section{References}

[1] Tian Benxiang. Classic Collection of Cao Yu’s Drama, Beijing: Xinhua Press, 2010.

[2] Tian Benxiang, Hu Shuhe. Cao Yu Research Materials, Beijing: China Theater Publishing House, 1991.

[3] Zhang Xiaohong. The Goddess on the Cross, Discussing the Causes of Camille's Tragedy. 2001, (2).

[4] Wu Yuetian. History of French Novels, Hangzhou: Zhejiang University Press, 2004.

[5] Alexandre Dumas. Camille, translated by Huang Jianian. Beijing: Changjiang Literature and Art Publishing House, 2006. 